\title{
The rise and demise of the New Public Management: Lessons and opportunities for South East Europe
}

UDK: 005:35(045)

\author{
Wolfgang Drechsler \\ Department of Public Administration, Tallinn University of Technology \\ drechsler@staff.ttu.ee
}

\begin{abstract}
The essay traces the rise and demise of New Public Management (NPM) during the last quarter of a century, as well as the emergence of a new public administration phenomenon, tentatively called the Neo-Weberian State (NWS), which is argued to be more suitable for coping with the current crisis and its aftermath as well. The essay then focuses on the optimal public administration system for South East Europe, for which the experience of the new Member States of the European Union is used for lesson-drawing. Here, too, it is argued that NPM is definitely not suited for the region, especially in current conditions but also generally. The NWS, in spite of several problems including those of context, remains the current concept of choice in the development of public administration in Europe, and as such can also be utilized in various ways in South East Europe.
\end{abstract}

Key words: New Public Management, Neo-Weberian State, South East Europe, new EU Member States.

JEL: H83, D73, P20, L33, H11.

It is particularly interesting to see what shape the public administration should take in South East Europe - specifically in the Western Balkan region, which may be defined, functionally for the present purposes, as the countries of former Yugoslavia, without Slovenia but including Albania. Public administration, after all, is the state in action, without which there is no state at all, and it 


\section{Wolfgang Drechsler \\ The rise and demise of the New Public Management: \\ Lessons and opportunities for South East Europe}

is one of the most vital paradigms of the modern world. It is especially relevant to the countries of the region during the current phase, marked both by internal transition and consolidation and moves towards EU accession, if to varying degrees, and made even more relevant by the current crisis and the reemergence of the state at the centre of development. Yet the ideal public administration structure is a moving target, as its form is not only contextspecific, but even the more abstract ideal is changing over time and currently in a state of flux and re-assertion worldwide. This essay therefore attempts to outline changes in the western concept of optimal public administration, i.e. the general goal of public management reform, and then to draw some lessons from the transition experience of the new EU Member States from Central and Eastern Europe, as arguably they experienced a similar experience some time previously.

\section{New public management and its demise}

The most important reform movement over the last quarter of a century in public administration has been New Public Management (NPM). NPM constitutes the transfer of business and market principles and management techniques from the private into the public sector, symbiotic with and based on a neo-liberal understanding of state and economy. The goal, therefore, is a slimlined, minimal state in which any public activity is decreased and, if at all, exercised according to business principles of efficiency. It is popularly denoted by concepts such as project management, flat hierarchies, customer orientation, abolition of career civil service, depolitisation, total quality management, and outsourcing. Transparency, citizen involvement, and decentralisation are not part of the original core of NPM, both theoretically - because the NPM focus on the apolitical rule of the expert makes them more difficult, and because they do not necessarily contradict previous forms of public administration at all - and empirically.

NPM comes from the Anglo-American sphere, and it was strongly pushed by most international finance institutions such as the World Bank and the IMF. It originates from the 1980s, a time characterised by the dominance of neoliberal governments and the perceived crisis of the welfare state and its financing, but it came to full fruition in the early 1990s. NPM was on the one hand a 
powerful trend within public administration scholarship and practice - which explains much of its power - and on the other, a genuine ideological concept.

As important and, though more rarely, as successful as several NPMinspired reforms of the public sector might have been and still may be, what one notices first when looking at the public and private spheres is the difference, not the similarity. The state is characterised primarily by its monopoly on power, force, and coercion on one side, and its focus on the public good, on the other, while the business world legitimately focuses on profit maximisation. The use of business techniques within the public sphere therefore miscomprehends the most basic requirements of any state, particularly of a democracy, seeing them as a liability; yet regularity, transparency, and due process are simply much more important than low costs and speed.

For this reason economic and theoretical management insights in particular could only establish themselves once the dominance of the NPM has passed, which as a genuine ideology was not even open to arguments stemming from its own leading method. NPM reforms created, for instance, quasimarkets within administrative organisations in order to generate market behaviour: yet, such behaviour can only develop in genuine and not in quasi (pseudo) markets. (See König, 2001, pp. 6-7)

Another example is the problem of the performance-related pay concept in relation to the demands of multitasking and motivation through identification with the organisation. As has been demonstrated particularly well by George Akerlof (Akerlof \& Kranton, 2003), every organisation must have employees who perform well (and cheaper) by identifying with the organisation, and that it is therefore a key requirement of a good organisation to engender employee identification with an organisation, therefore creating "motivational capital" (p. 29). Akerlof points out the problems denoted by the concept of "multitasking," well investigated by Bruno Frey and his school (see Frey, 2007, pp. 209-212 for an excellent summary), with performance-related pay and monetary incentives only, which is a hallmark of NPM and perhaps the cornerstone of its employment culture; he adds that overstrict supervision leads to less quality and a declining output (Akerlof \& Kranton, 2003, pp. 11, 22-26). As Frey writes, "For no position - except perhaps the most simple assembly line work - can all relevant aspects be defined and measured" (Frey, 2007, p. 209). Akerlof consciously validates his work by linking it to Weber's concept that successful bureaucracies are based on the motto "an office is a vocation" with all this implies (Akerlof \& Kranton, 2003, p. 29). NPM therefore acts and looks like 


\section{Wolfgang Drechsler \\ The rise and demise of the New Public Management: Lessons and opportunities for South East Europe}

the application of business and management techniques to the public sector, but not only in an inappropriate and simplistic, but also in an obsolete way.

But even by the standards of business efficiency, NPM cannot be said to be successful from today's perspective. For many years it has been clear that there is no empirical evidence that NPM reforms have led to any productivity increase or welfare maximisation (König, 1997, p. 214). The most that may be claimed is that "several years of attempts and experiences of public management reforms in western Europe and other OECD countries give evidence of relative failure rather than success" (van Mierlo, 1998, p. 401). Empirically, the catchword promises have not been delivered - flat hierarchies are a matter of appropriateness and depend in their suitability entirely on context; treating citizens merely as customers takes away their participatory rights and duties and thus harms the state; the abolition of career civil service will usually lead to the erosion of administrative capacity; depolitisation - and thus dedemocratisation - leads to the return of the imperial bureaucrat (in its worst sense, disguised as the entrepreneurial bureaucrat: same power, less responsibility); and outsourcing has proven to be excessively expensive and often infringes on the state's core competences, as well as on the most basic standards of equality. Quality management is not necessarily an NPM concept and can just as easily be applied elsewhere and was actually always understood to be part of a well-working PA; project management may frequently work, but as a principle and in the long run, it is more expensive and less accountable than the traditional approach.

In advanced public administration scholarship itself then, particularly - but not only - in Europe, advocates of NPM are now heavily on the defensive, if NPM is proposed as a world view (i.e. an ideology), rather than as one of several useful perspectives for public administration reform (i.e. part of the "tool box"). What was an option fifteen years ago is simply not an option anymore today. One could mark the following stages in public administration development:

- around 1995, it was still possible to believe in NPM, although there were first strong and substantial critiques;

- around 2000, NPM was on the defensive, as empirical findings spoke clearly against it as well;

- $\quad$ around 2005, NPM was no longer considered a viable concept. 
Wolfgang Drechsler

The rise and demise of the New Public Management: Lessons and opportunities for South East Europe

In other words, it has become quite rare in the last five to ten years, and is becoming rarer still, to see articles in the very top journals, or essays and keynote addresses by the very top public administration scholars - particularly in Europe, but also in the United States - that are based on or implicitly assume the validity of NPM.

Yet, in many areas of scholarship and of the world, and particularly in policy, NPM is very much still alive and kicking (i.e. the farther one departs from academia above all and from Europe or international and central government). This is also true at the level of the EU and many Member States, where it strikes a chord with the predominant world view or views (See Drechsler, 2009a).

Nevertheless, particularly at the local and regional levels, many communities have in recent years, and after careful deliberation, acted against NPM reforms, even in traditional NPM strongholds (See Schäfer, 2008). The justifications for stopping NPM reforms given by the city of Dübendorf (Zurich) in Switzerland provide a fair summary: "No improvements of efficiency, effectiveness or quality could be attributed to NPM reforms" (Noordhoek \& Saner, 2005, p. 38). Shortly before the global economic crisis, the news that New Zealand, the most famous trailblazer of NPM reforms, was buying back its privatised railway system because privatisation had proved disastrous for economic development, investment, and innovation (a standard justification for privatisation) is the most notable nail in the coffin for NPM (See http://www.beehive.govt.nz/release/rail+buy+back+marks+new+sustainable+ era+transport for the official government announcement).

When the global financial meltdown hit in autumn 2008, it took the most market-oriented circles a week at most to change full swing and demand that the state come to the rescue. It also changed, for a while, public and political attitudes towards bureaucracy in general, and the critique of NPM as formulated above seemed almost trivial. It seemed clear that the NPM phrases, logic, and entire way of thinking was of the same mindset that had caused, or at least triggered, the crisis to begin with: a naïve faith in simplified laissez-faire economics and the predictably negative role of the state. However, when the economy seemed to rebound in the summer of 2009, this was rapidly forgotten by many NPM advocates, so that at present while some countries and public institutions have retracted and are heading in the direction that will be outlined below, others believe that now is the time for NPM reforms. Yet this is no longer under the mantle of "better service for less money" but merely 
Wolfgang Drechsler

The rise and demise of the New Public Management:

Lessons and opportunities for South East Europe

in order to spend less (Peters, forthcoming). However, it is clear to most observers that now the time has come for alternatives to NPM.

\section{The Neo-Weberian state}

The counter-model to NPM, indeed its bête noire, is what is called Weberian public administration. This label is highly problematic, as NPM presents a caricature of it and thus builds up a paper tiger. Apart from the caricature, for Weber, the most efficient public administration was a set of offices in which appointed civil servants operated under the principles of merit selection (impersonality), hierarchy, division of labour, exclusive employment, career advancement, the written form, and legality. This increase of rationality - his key term - would increase the speed, scope, predictability, and cost-effectiveness required for an advanced mass-industrial society (Weber, 1922, esp. pp. 124130).

It seems that fundamentally, with all its weaknesses, the Weberian model is still the best around, and is certainly superior to the NPM; to paraphrase Churchill, it is the worst form of public administration except all others. The connection between Weberianism and economic growth seems, in any case, very close (See Evans \& Rauch, 1999).

Nevertheless, the optimal administrative structure of our times - whether pre-crash, post-crash, or mid-crash - does not consist of a simple rehash of the organisation principles of the mass production paradigm, whose weaknesses are amply known from excessive legalism via genuine bureaucracy to genuine antagonism to innovation and the economy. NPM also offers some managerialist elements and even larger principles which as such could be judged positively, as long as they do not form the basis of the system, and there must be some adaptation to best match current circumstances with their different challenges, demands, and socio-intellectual context.

The most discussed model for the administrative paradigm to follow NPM, i.e. post-NPM, is not therefore a return to the previous one, but according to the concept of Pollitt and Bouckaert proposed in 2004, the so-called Neo-Weberian State (NWS), a fortuitous metaphor describing a model that coopts the positive elements of NPM, but on a Weberian foundation, so that 
Wolfgang Drechsler

The rise and demise of the New Public Management: Lessons and opportunities for South East Europe

both are, asymmetrically, deemed as superceded (Pollitt \& Bouckaert, 2004, pp. 96-102). One can briefly sum up the NWS as follows:

Table 1: The Neo-Weberian State (summary)

\begin{tabular}{|c|c|}
\hline Neo-Weberian & Weberian \\
\hline $\begin{array}{l}\text { Shift from an internal focus on bureaucratic } \\
\text { rules to an external focus meeting citizens' } \\
\text { needs and wishes. The primary route to } \\
\text { achieving this is not applying market } \\
\text { mechanisms (although they may occasion- } \\
\text { ally prove useful) but the creation of a } \\
\text { professional culture of quality and service. }\end{array}$ & $\begin{array}{l}\text { Reaffirmation of the role of the state as } \\
\text { the main facilitator of solutions to the } \\
\text { new problems of globalisation, techno- } \\
\text { logical change, shifting demographics, } \\
\text { and environmental threat. }\end{array}$ \\
\hline $\begin{array}{l}\text { Supplementation (not replacement) of the } \\
\text { role of representative democracy with a } \\
\text { range of devices for consultation with, and } \\
\text { direct representation of citizens' views. }\end{array}$ & $\begin{array}{l}\text { Reaffirmation of the role of representative } \\
\text { democracy (central, regional, and local) as } \\
\text { the legitimating element within the state } \\
\text { apparatus. }\end{array}$ \\
\hline $\begin{array}{l}\text { In resource management within govern- } \\
\text { ment, a modernisation of the relevant laws } \\
\text { to encourage greater focus on achieving } \\
\text { results rather than merely following proce- } \\
\text { dure correctly. This is expressed partly in a } \\
\text { shift from ex ante to ex post controls, } \\
\text { without a complete abandonment of the } \\
\text { former. }\end{array}$ & $\begin{array}{l}\text { Reaffirmation of administrative law - } \\
\text { suitably modernised - in preserving the } \\
\text { basic principles pertaining to the citizen- } \\
\text { state relationship, including equality be- } \\
\text { fore the law, legal security, and the avail- } \\
\text { ability of specialized legal scrutiny of state } \\
\text { actions. }\end{array}$ \\
\hline $\begin{array}{l}\text { Professionalisation of public services, so } \\
\text { that the bureaucrat becomes not simply an } \\
\text { expert in the law relevant to his or her } \\
\text { sphere of activity, but also a professional } \\
\text { manager, focused on meeting the needs of } \\
\text { his or her citizens/users. }\end{array}$ & $\begin{array}{l}\text { Preservation of the idea of a public ser- } \\
\text { vice with a distinct status, culture, and } \\
\text { terms and conditions. }\end{array}$ \\
\hline
\end{tabular}

Source: Pollitt \& Bouckaert, 2004, pp. 99-100 


\section{Wolfgang Drechsler \\ The rise and demise of the New Public Management: \\ Lessons and opportunities for South East Europe}

The NWS was intended as an empirical-analytical, not as a normative model, and one of its creators, Pollitt, is quite self-critical about several of its aspects, nor is this the only criticism around (See Pollitt et al., 2009, as well as Dunn \& Miller, 2007). And yet, the NWS is to date perhaps the best explanatory model of what is going on in Europe, and it does not throw good managerialist - and participatory - principles out when rejecting NPM as a whole. It is still very much part of the research agenda, but in lieu of anything better, it significantly helps our understanding of contemporary public administration.

In fact, the NWS is the perfect match for an innovation-based society, in contrast to NPM. When dealing with innovation-based economics, the foundation of the Lisbon Agenda, the EU's main development programme, there is an immense push-pull function form what is, after all, a state-based socioeconomic development programme that asks for, draws upon, and requires high-quality public administration to implement it (Drechsler, 2009a). Innovation in the general interest, rather than that of an individual entrepreneur, is a question of successful innovation policy, and who should implement that, if not the administration? Whatever the future leading technologies will be - nanotech, biotech, convergence or something completely different - its setup will require a particularly capable state actor and a science and technology policy implemented by a civil service that is denoted by long-term planning, high competence, and tolerance for mistakes: the opposite of NPM (Drechsler, 2008). Innovation is a matter of state, as Claude Rochet puts it succinctly (2007).

It should further be emphasised for the current ICT paradigm that egovernance and NPM are not actually related, as is usually assumed because they seem to share certain features. Almost none of the traditional Weberian categories became obsolete through ICT (potentially, exclusive employment does, which may be a problem for the nucleus of civil service), while some such as the written principle and division of labour - are actually enforced. In the most prominent case of hierarchy, there are mixed dynamics, as it is weakened by network models of organisation but strongly enforced via the extreme control and coordination capabilities of ICT. Overall e-governance and the NWS can reinforce each other, and in fact seem to do so (See Dunleavy et al., 2005, 2006).

Finally, the NWS seems to be the best model available for public administration in times of crisis - or at least, during the current crisis. Whether one likes the state or not (and it often comes down to just that), the return of the state into the economy, on a scale unimaginable in mid-2008, means that our 
Wolfgang Drechsler

The rise and demise of the New Public Management: Lessons and opportunities for South East Europe

system cannot function without a genuinely competent and motivated civil service, and that cutting public expenditure at least in this realm is the worst idea imaginable. The new big state is already there - and it is in the interest of everyone, anywhere (excepting a few profiteers), that it is well-administered. In fact, it may even be argued that the best hope for managing both the crisis and later recovery well is the return of the mandarin, i.e. of a highly capable, responsible, motivated, long-term focused senior civil service, among other Neo-Weberian and indeed traditional Weberian institutions.

\section{Lessons and opportunities for South East Europe}

But what does this all mean for South East Europe? In fact, the crisis itself has not manifested itself in any specific manner in this region, so one must consider any particular features of the region that would make the NPM and NWS appropriate or inappropriate (and regarding the latter, there is certainly a basic question regarding the applicability of Weberianism, old or new, to this region) in themselves, or as a reservoir of good practices. This can be done by looking at pre-crash experiences. For South East Europe, it would be necessary to look at the individual countries, their background, traditions, human and other resources, and specific questions such as the state of neo-liberalism in Serbia, the prevalent civil service payment systems in Macedonia, and the legacy of the Venetian Republic's administration in Montenegro. That is beyond the remit of this essay, if for no other reason than for that of space. Specifically in relation to the applicability of the NPM, however, a set of countries that has recently undergone similar experiences and decisions exists: the new EU Member States in Central and Eastern Europe (a term that will also be applied to them during their accession period) - including Slovenia. Acknowledging any differences and specific features and with all the problems of lessondrawing as such (see Randma-Liiv, 2007, specifically about Central and Eastern Europe) understood, one can still state that the debate on the use of NPM in the new Member States is similar enough to that facing South East Europe right now to be of use in gaining insight into what actions would be beneficial, and what actions to avoid in the region, with lessons for the times of crisis and beyond. 


\section{Wolfgang Drechsler \\ The rise and demise of the New Public Management: Lessons and opportunities for South East Europe}

For one reason or another, serious comprehensive evaluations of the new Member States' experiences in public administration from an ex-post perspective still seem to be missing (an exception is the brilliant Randma-Liiv, 2009), but one may already state generally that the main problem for new Member States in this sphere was not structures, which are formally easy to replace, but people, who are not. The main problem in the new Member States, in other words, was the lack of well-qualified, motivated civil servants.

The problem is that good public administration, a high-quality civil service, and a good understanding of the concept of state are interdependent: if one element is bad, the other two will suffer as well (Drechsler, 2000, p. 5). Public administration appears to require a special virtue - loaded though that word is - on the part of its main protagonist, the civil servant, in order for the system to function well or even at all. This virtue cannot be created artificially and is highly dependent on tradition. How, then, can a good civil service be developed, if there is neither good tradition nor ethos, which was the situation generally faced by the new Member States? High civil service pay would be an answer, but in most of the new Member States, the consensus was that this cannot be afforded - or that the civil service is paid far too well anyway. Furthermore, as described above, performance-related pay, which seemed to be the solution, does not work. Thus, one had to go back (but did not always do so) to the old insight that the state must offer what the state can offer best: the classic virtues of security, respect, stability, civility, and fulfilment - the opposite of NPM measures. If the state does this, it will in turn become more prestigious to work in the public administration. Ideally, this should lead to a greater general faith in the state and the emergence of a decent concept of state, which again will result in a higher civil service prestige - and so on, and so forth.

What was generally true for public administrations in the new Member States was that it was a nomenclature administration before the 1989/91 revolutions; where members of the cadre "were professional administrators, but with politically and ideologically defined qualifications." (König, 1997, p. 215) That means that their experience was not necessarily valid, and their competence might have been low. In addition, many fields of administration - from fiscal to municipal - were generally deficient. So, the question was not only, or even primarily, one of downsizing, but rather one of building instead of reforming a functioning public administration system, which is invariably costly. And 
Wolfgang Drechsler

The rise and demise of the New Public Management: Lessons and opportunities for South East Europe

indeed, there was no genuine downsizing at all, only the rhetoric of downsizing (Drechsler, 2003).

In addition to the transition experience, the EU accession process was the second key feature for all new Member States, as it is now for the South East European region. The increase of administrative capacity, that is public administration reforms geared towards high quality, was primarily EU-driven in the new Member States. It may well be that the administrative capacity of the new Member States was highly deficient in according to EU requirements right until accession, and that "the EU has been far from consistent in the signals it has sent to the candidate states" (Verheijen, 2000, p. 41). Yet the extent to which the public administrations of the new Member States appeared successful - particularly regarding the (pre-crash) success in the case of Slovenia, Hungary, and Estonia - was largely due to the EU accession process.

Even before EU accession became realistic, however, the self-chosen public administration models for the new Member States were often Germany and Sweden, and far less often the United States, and certainly not Britain (Rose, 1993, pp. 113-144). Therefore, it was not surprising to see that "traditional continental career systems appear to be the main source of inspiration for Central and Eastern European states. The German model is emerging, at the current time, as a dominant influence in most states. ... In general ..., there appears to be a clear tendency to return to the continental roots' of pre1945" (Verheijen, 1999, pp. 330-331). Thus, often "the foundations were being laid to build an administrative elite shaping a Weberian-style bureaucracy under the authority of elected politicians" (Cardona, 2000, p. 3), particularly in Hungary and to some extent in Slovenia. (Unfortunately, it goes beyond the scope of this essay to look at the specifically Austrian influence in South East Europe today and over recent decades, but this would be an important path to pursue in this context.)

After that which has been said about the power of the NPM creed during the 1990s, and given the frequent role of neo-liberal governments in new Member States around that time, this requires some explanation. First, while public administration reform in the new Member States was promoted by various international organisations, what made the difference was that SIGMA, the OECD unit advising Central and Eastern Europe states on administrative reform (the most important agency dealing with the topic in the region, far more ubiquitous than the World Bank), took a critical perspective towards NPM from the beginning. Therefore, in spite of pressure from other organisations and 


\section{Wolfgang Drechsler \\ The rise and demise of the New Public Management: \\ Lessons and opportunities for South East Europe}

the understandable urge by consultants and by those people from the new Member States engaged in reform who had learned about NPM in summer schools and training seminars in the west and thus became its advocates, the classical perspective could usually prevail (See Speer, 2001, pp. 85-86). Perhaps even more important was the explicit preference of the EU for a traditional public administration (Verheijen, 1999, p. 337), never mind its own engagement with NPM ideas and reforms, which also mostly came a decade later ("Kinnock Reforms") (See Drechsler, 2009a; Bauer, 2006). Both the very direct demands and the accession trajectory towards a self-satisfied, well-paid, traditional civil service of enormous proportions with all the advantages and drawbacks would have made NPM reforms rather a waste of effort and money.

However, in addition to these external reasons, there were internal reasons that meant NPM was particularly unsuitable for the new Member States, which lay more in the transition experience than in the EU trajectory. As JJ Hesse writes, "the introduction of business approaches in public administration, as advocated by NPM concepts, may well prove disastrous in systems based on a continental European tradition in which either the preconditions may not be in place or where they may be rejected due to their inherent logic" (1998, p. 176). NPM is particularly bad if pushed upon transition and development countries because if it can make any sense, then it is only in an environment of a well-functioning democratic administrative tradition. After all, deregulating "the public service may not be viable before there is a set of values that will permit government to operate in an accountable and non-corrupt manner without the existence of formalized controls" (Peters, 2001, p. 167).

This was seen within the new Member States as well. A 2002 study based on interviews with civil servants in several of these countries concluded that NPM "is also known for its tendency to re-establish political control over the civil service, which is exactly the opposite of what $100 \%$ of interviewees of this study considered desirable for their countries. So, in at least one very important aspect, i.e. the relations between civil service and government, the NPM approach appears to be highly unsuitable, given the current needs" (King, 2002 , p. 4). As the key democratic requirement of transparency is one of the first victims of any form of NPM (Haque, 2001), "frequently NPM-defined effectiveness and efficiency bring about a decrease in accountability and responsibility, and in that way are undemocratic" (Debicki, 2003, p. 35). That, however, is 
Wolfgang Drechsler

The rise and demise of the New Public Management: Lessons and opportunities for South East Europe

nowhere more problematic than in countries where the main order of the day is to establish a democratic state, rather than to cut costs.

Therefore, the lesson from the new Member States to South East Europe is clearly not to adopt NPM as a paradigm (rather than specific NPM tools). As Guy Peters stated:

"Despite the appeal of ideas such as deregulation and flexibility, governments attempting to build both effective administration and democracy might require much greater emphasis on formality, rules, and strong ethical standards. The values of efficiency and effectiveness are important but in the short run not so crucial as creating probity and responsibility. Once a so-called Weberian administrative system is institutionalized, then it may make sense to consider how best to move from that system towards a more "modern" system of public administration" (2001, p. 176; see also p. 164; Randma-Liiv, 2009).

And Klaus König has pointed out that a lesson that specifically East Germany can teach the other Central and Eastern European countries - and now South East Europe - is to create the classical continental public administration system first, which answers the specific problems of delegitimisation and other typical problems (König, 2001, pp. 195-199):

"The application of contract management in Central and Eastern Europe makes it very difficult to build up a modern functional system of public administration which contains basic qualities and ethical standards according to the Western model; negotiating and executing the contracts leads to high transaction costs... (p. 197) Only when a well-educated public service with the basic values of administrative ethics is in place and if a system of clear responsibilities prevails, so that measures for good public performance can be defined and its costs are transparent, only then are the prerequisites created for the decision into which direction a reform process should go. ... It may be more important, depending on the local situation, to create legal certainty via a fixed order of responsibility, rather than to tap reserves of rationalization through simulated competition" (p. 198).

The first great opportunity offered by the lessons of the new Member States for South East Europe is to avoid the NPM phase altogether, without ignoring the important lessons from NPM and the powerful NPM tools. We know now that NPM "clean-ups" cannot solve the problems of incompetence and lack of democracy in a bureaucracy that are a hangover from the previous 


\section{Wolfgang Drechsler \\ The rise and demise of the New Public Management: Lessons and opportunities for South East Europe}

regime, nor those of corruption - it cannot be done, however desirable that may be. And this is clearly a pre-crash lesson.

The second opportunity lies in the concept of the NWS, and goes beyond the experience of the new Member States, because the NWS was not yet in place as a concept for most of their transition, only appearing towards the end of that phase. Nonetheless, the NWS, as a viable and well-supported alternative that allows one not only to criticise NPM but to concretely present a quite coherent, contemporary, modern model of what a public administration should look like is something that was not available to the new Member States. This is a fringe benefit that the comparatively late transition offers South East European countries, from which they can garner a serious advantage. This is all the more so because the NWS, by its syncretistic nature, does combine the best of both worlds, while leaving ample room for national specifics on the other. And this is the case under the conditions of the current crisis as well, even more so than before. This does not mean that the NWS should or even can be adopted in its entirety in South East Europe, especially because it may well be argued that the region never had an old Weberian tradition, but its insights can certainly be helpful.

There will always be advisors, politicians, and stakeholders who will advocate NPM, whether because they think it is still the fashion, because of genuine ideology, or because they really see it as the best solution to the problems at hand, and currently, because they think it saves money that must be saved. So, there will always be throwbacks in the development of public administration in the region. Nevertheless, the general direction into which public administration in South East Europe should head is reasonably clear. As Aristotle says in the Politika, "a state comes into existence for the purpose of ensuring survival, and it continues to exist for the purpose of the good life" (Arist., Pol. I 1252b). And as Marsilius of Padua comments upon this passage, the latter, the good life, "is the perfect final cause of the state" (Defensor pacis I. iv.1.). A good life in a good state in South East Europe, as diverse as the region may historically, economically, and culturally be, yet consolidated and heading towards EU membership, geared towards peaceful and productive coexistence in the globalized, competitive environment of the $21^{\text {st }}$ century beyond the current crisis, is unthinkable without a high-quality, appropriate, well-working public administration and a responsible, responsive, competent and trustworthy civil service, which is also crucial for weathering the effects of the crash as they continue to unfold. The best model (to look at, not to copy) for such an 
Wolfgang Drechsler

\section{The rise and demise of the New Public Management:} Lessons and opportunities for South East Europe

ideal currently appears to be the Neo-Weberian State (or something of its kind or even beyond it); it is certainly not New Public Management.

\section{Acknowledgments}

This essay is based on the keynote address of the same title for the $2^{\text {nd }} \mathrm{In}$ ternational Symposium on the Development of Public Administration in South East Europe, University of Ljubljana and NISPAcee, Ljubljana, 19 June 2008; it was updated in November 2009 in order to situate its argument within the context of the current crisis. Sections 1 and 2 were based on several previous publications, especially Drechsler, 2005b and, more recently, 2008 and 2009a; section 3, on Drechsler, 2005a; thoughts on the crisis came from Drechsler, 2009c and especially from "The Neo-Weberian State: Public Administration Paradigm for the Current Crisis?" a plenary paper delivered at the $7^{\text {th }}$ Portuguese National Congress of Public Administration on "The State and Administration in the Answer to the Crisis", Lisbon, 10 November 2009. I am grateful to Mirko Vintar and Stanka Setnikar-Cankar for their kind invitation and hospitality and for the participants of the conference for their excellent feedback during the discussion session, to Tiina Randma-Liiv and Ingbert Edenhofer for commenting on the essay version, and to the staff of the Portuguese National Institute of Public Administration for discussing the crisis perspective. Support from the Estonian Science Foundation (grant no. 7577) and the Estonian National Research Scheme (grant no. SF0140094s08) for the research upon which this essay is based is gratefully acknowledged.

Wolfgang Drechsler is Professor and Chair of Governance at Tallinn University of Technology, Estonia, and co-director of its graduate Technology Governance program. He has served as Ad-visor to the President of Estonia, as Executive Secretary with the German Wissenschaftsrat during German Reunification, and as a Senior Legislative Analyst in the United States Congress (APSA Congressional Fellow). He is a member of the NISPAcee Steering Committee and, as the public management expert, of the Lisbon Agenda Group. 
Wolfgang Drechsler

The rise and demise of the New Public Management:

Lessons and opportunities for South East Europe

\section{References}

- Akerlof, George A., \& Kranton, Rachel E. (2005). Identity and the Economics of Organizations. Journal of Economic Perspectives (9: 1), 9-32.

- Bauer, Michael W. (2006). Die Reform der europäischen Kommission: Eine Studie zur Managementmodernisierung internationaler Organisationen. Verwaltungsarchiv (97: 3), 270-292.

- Cardona, Francisco. (2000). Scope of Civil Services in European Countries: Trends and Developments. Paris: SIGMA.

- Debicki, Marek. (2003). Public Service in a Corporate World - The Dangers of Managerialism as a Tool for Public Administration. In Finlay, Jane, \& Debicki, Marek (Eds). Delivering Public Services in Central and Eastern European Countries: Trends and Developments. Bratislava: NISPAcee, 27-36.

- Drechsler, Wolfgang. (2009a). Lisbon Agenda and Public Administration. In Rodrigues, Maria João Rodrigues (Ed.). Europe, Globalisation and the Lisbon Agenda. Cheltenham Northampton, MA: Edward Elgar, 294-309.

- Drechsler, Wolfgang. (2009b). NanoGov - Nanotechnologie, Innovation, Governance und Verwaltung aus der Perspektive der Techno-Ökonomischen Paradigmen. In Scherzberg, Arno, \& Wendorff, Joachim (Eds). Nanotechnologie - Grundlagen, Anwendungsfelder, Regulierung. Berlin - New York: de Gruyter, 307-325.

- $\quad$ Drechsler, Wolfgang. (2009c). Towards a Neo-Weberian European Union? Lisbon Agenda and Public Administration. Halduskultuur - Administrative Culture (10), 6-21.

- Drechsler, Wolfgang. (2008). Aufstieg und Untergang des New Public Management. Kurswechsel (23: 2), 17-26.

- Drechsler, Wolfgang. (2005a). The Re-Emergence of Weberian Public Administration after the Fall of the New Public Management: The Central and Eastern European Perspective. Halduskultuur (6), 94-108.

- $\quad$ Drechsler, Wolfgang. (2005b). The Rise and Demise of the New Public Management. Post-autistic economics review (33), 14 September, at http://www. paecon.net/PAEReview/issue33/Drechsler33.htm.

- Drechsler, Wolfgang. (2003). Lessons for Latin America and the Caribbean in Managing Public Sector Restructuring: Public Sector Downsizing and Redeployment Programs in Central and Eastern Europe. Study for the Regional Policy Dialogue, Public Policy Management and Transparency Network. Washington, DC: Inter-American Development Bank, at http://idbdocs.iadb.org/wsdocs/getdocument.aspx?docnum=623667. 
- Drechsler, Wolfgang. (2000). Public Administration in Central and Eastern Europe: Considerations from the "State Science" approach. In Castro, Ana Célia, Burlamaqui, Leonardo, \& Chang, Ha-Joon (Eds). Institutions and the Role of the State. Cheltenham Northampton, MA: Edward Elgar, 267-279.

- Dunleavy, Patrick, Margetts, Helen, Bastow, Simon, \& Tinkler, Jane. (2006). Digital Era Governance: IT Corporations, the State and E-government. Oxford: Oxford University Press.

- Dunleavy, Patrick, Margetts, Helen, Bastow, Simon, \& Tinkler, Jane. (2005). New Public Management Is Dead - Long Live Digital-Era Governance. Journal of Public Administraion Research and Theory (16), 467-494.

- Dunn, William N., \& Miller, David Y. (2007). A Critique of the New Public Management and the Neo-Weberian State: Advancing a Critical Theory of Administrative Reform. Public Organization Review (7), 345-358.

- Evans, Peter, \& Rauch, James E. (1999). Bureaucracy and Growth: A Cross-National Analysis of the Effectiveness of Weberian State Structures on Economic Growth. American Sociological Review (64), 748-765.

- Frey, Bruno S. (2007). Evaluierungen, Evaluierungen ... Evaluitis. Perspektiven der Wirtschaftspolitik (8: 3), 207-220.

- Haque, M. Shamsul. (2001). The Diminishing Publicness of Public Service under the Current Mode of Governance. Public Administration Review (61: 1), 65-82.

- Hesse, Joachim Jens. (1998). Rebuilding the State: Administrative Reform in Central and Eastern Europe. In Preparing Public Administration for the European Administrative Space. SIGMA Papers, 23. Paris: Sigma, 168-179.

- King, Roswitha M. (2002). What Kind of Civil Service? Trends in Public Administration Reform in Eastern Baltic Sea States. Manuscript at www.cerge-ei.cz/pdf/gdn/RRCl_64_summary.pdf

- König, Klaus. (2001). Zum Governance-Begriff. In König, Klaus, \& Adam, Markus (Eds). Governance als entwicklungspolitischer Ansatz. Speyer: Forschungsinstitut für öffentliche Verwaltung, 1-9.

- König, Klaus. (1997). Entrepreneurial Management or Executive Administration: The Perspective of Classical Public Administration. In Kickert, Walter J.M. (Ed.). Public Management and Administrative Reform in Western Europe. Cheltenham Northampton, MA: Edward Elgar, 213-232.

- Noordhoek, Peter, \& Saner, Raymond. (2005). Beyond New Public Management: Answering the Claims of Both Politics and Society. Public Organization Review (5), 35-53.

- Peters, B. Guy. (forthcoming). Bringing the State Back In One More Time: The changing Role of State, Society, and Markets in Governance. NISPAcee Journal of Public Administration and Policy (3: 1). 
Wolfgang Drechsler

The rise and demise of the New Public Management:

Lessons and opportunities for South East Europe

- $\quad$ Peters, B. Guy. (2001). The Future of Governing, $2^{\text {nd }}$ rev. edn. Lawrence, KS: Kansas University Press.

- Pollitt, Christopher, \& Bouckaert, Geert. (2004). Public Management Reform. A Comparative Analysis. $2^{\text {nd }}$ edn. Oxford: Oxford University Press.

- Pollitt, Christopher, Bouckaert, Geert, Randma-Liiv, Tiina, and Drechsler, Wolfgang (Eds). (2009). A Distinctive European Model? The Neo-Weberian State. NISPAcee Journal of Public Administration and Policy (1: 2, 2008/2009).

- Randma-Liiv, Tiina. (2009). New Public Management versus Neo-Weberian State in Central and Eastern Europe. In Pollitt, Christopher, Bouckaert, Geert, Randma-Liiv, Tiina, and Drechsler, Wolfgang (Eds). (2009). A Distinctive European Model? The NeoWeberian State. NISPAcee Journal of Public Administration and Policy (1: 2), 69-81.

- $\quad$ Randma-Liiv, Tiina. (2007). From Policy Transfer to Policy Learning in Central and Eastern Europe. In Coombes, David, \& Vass, Laszlo (Eds). Post-Communist Public Administration: Restoring Professionalism and Accountability. Bratislava: NISPAcee, 27-36.

- Rochet, Claude. (2007). L'innovation, une affaire d'état. Paris: L'Harmattan.

- Rose, Richard. (1993). Lesson-Drawing in Public Policy: A Guide to Learning across Time and Space. Chatham, NJ: Chatham House.

- Schäfer, Roland. (2008). Privat vor Staat hat ausgedient. Rekommunalisierung: Modetrend oder neues Politikphänomen? Frankfurter Allgemeine Zeitung, Öffentliche Finanzen supplement, 20 June.

- Speer, Benedikt. (2001). Das SIGMA-Programm der OECD: Ein Governance-Ansatz für Mittelund Osteuropa? In König, Klaus, \& Adam, Markus (Eds). Governance als entwicklungspolitischer Ansatz. Speyer: Forschungsinstitut für öffentliche Verwaltung, 67-87.

- Van Mierlo, Hans. (1998). Lessons from the Experience of OECD Countries. In Verheijen, Tony, \& Coombes, David (Eds). Innovations in Public Management. Perspectives from East and West Europe. Cheltenham - Northampton, MA: Edward Elgar, 388-403.

- Verheijen, A.J.G. Š. Tony. (2000). Administrative Capacity Development - A Race Against Time? WRR Scientific Council for Government Policy Working Document W107. The Hague: WRR.

- Verheijen, Tony. (1999). Conclusions. In Verheijen, Tony with Kotchegura, Alexander (Eds). Civil Service Systems in Central and Eastern Europe. Cheltenham - Northampton, MA: Edward Elgar, 327-338.

- Weber, Max. (1922). Grundriß der Sozialökonomie, 3: Wirtschaft und Gesellschaft. Tübingen: Mohr Siebeck. 


\section{POVZETEK}

\section{VZPON IN PROPAD NOVEGA JAVNEGA MENEDŽMENTA: LEKCIJE IN PRILOŽNOSTI ZA JUGOVZHODNO EVROPO}

V Jugovzhodni Evropi je še posebno zanimivo pogledati, kakšno obliko naj bi privzela javna uprava. Javna uprava je konec koncev država $v$ delovanju, prvina, brez katere države sploh ni, poleg tega pa je tudi ena od najvitalnejših paradigem današnjega sveta. Še posebno je pomembna za države regije, ki jo trenutno zaznamujejo - čeprav različno - notranja tranzicija in konsolidacija ter proces pridruževanja Evropski uniji (EU), njen pomen pa sta še okrepili trenutna kriza in ponovna pojavitev države na osrednjem prizorišču razvoja. Idealna struktura javne uprave je gibljiva, saj njena oblika ni specifična samo glede na okoliščine, temveč se $s$ časom spreminja tudi njen abstraktnejši ideal, ki je trenutno povsod po svetu negotov in se znova uveljavlja. $V$ tem članku želimo torej orisati spremembe "zahodnega" koncepta optimalne javne uprave, tj. splošnega cilja reforme javne uprave, nato pa pridobiti spoznanja iz tranzicijskih izkušenj tistih novih držav članic EU, ki so del Srednje in Vzhodne Evrope, saj so najverjetneje šle skozi podobne procese.

Najpomembnejše reformno gibanje zadnjega četrt stoletja $v$ javni upravi kot taki je novi javni menedžment (NJM), tj. prenos poslovnih in tržnih načel ter upravljavskih tehnik iz zasebnega $v$ javni sektor, in sicer $v$ simbiozi z neoliberalnim pojmovanjem države in gospodarstva ter na njegovi podlagi. Glede na sodobno javnoupravno vedo je NJM zlasti - vendar ne samo - v Evropi trenutno močno $v$ defenzivi, če ga razumemo kot svetovni nazor (tj. ideologijo), ne pa kot eno od več koristnih perspektiv za reformo javne uprave (tj. „orodje“). Nenadni globalni finančni zlom jeseni 2008 je spremenil tudi javni in politični odnos do birokracije na splošno, kritika NJM, kakor je izražena zgoraj, pa je bila videti skoraj trivialna - in bilo je kot na dlani, da imajo fraze, logika in celoten način razmišljanja NJM prav tisto miselno podstat, ki je sprva povzročila oziroma vsaj sprožila krizo, naivno vero $v$ gospodarski liberalizem in predvidljivo negativno vlogo države.

Protimodel NJM, pravzaprav njegov "grdi raček", je tako imenovana Weberjanska javna uprava. Kaže, da je weberjanski model z vsemi slabostmi vred v bistvu še vedno najboljši, zagotovo pa je boljši od NJM - saj je, če uporabimo Churchillove besede, najslabša oblika javne uprave, razen 


\section{Wolfgang Drechsler \\ The rise and demise of the New Public Management: \\ Lessons and opportunities for South East Europe}

vseh drugih. Optimalna struktura uprave našega časa - ni pomembno, ali pred zlomom, po njem ali med njim - pa vseeno ne pomeni preproste predelave organizacijskih načel paradigme množične proizvodnje, katere slabosti so dobro znane - od pretiranega legalizma prek pristne birokracije do zagrizenega nasprotovanja inovaciji in gospodarstvu. Model upravne paradigme, ki sledi NJM in o katerem je že nekaj let največ govora, tj. post-NJM, zato ne pomeni vrnitve k prejšnjemu, temveč v skladu s Pollittovim in Bouckaertovim konceptom iz leta 2004 pomeni tako imenovano neoweberjansko državo (NWD), metaforo za opis modela, ki sicer prevzema pozitivne prvine NJM, vendar na weberjanskem temelju, tako da sta oba asimetrično aufgehoben.

Zdi se, da je NWD najboljši model javne uprave, ki nam je na voljo $v$ kriznih časih - oziroma vsaj med sedanjo krizo. Najsi bo država človeku všeč ali ne, njena vrnitev $v$ gospodarstvo $v$ obsegu, ki je bil še sredi leta 2008 nepredstavljiv, pomeni, da naš sistem ne more delovati brez resnično usposobljene in motivirane državne uprave ter da je zmanjševanje javnih izdatkov na tem področju najslabša mogoča zamisel.

Kaj pa vse to pomeni za Jugovzhodno Evropo? Kriza se v tej regiji dejansko ne kaže nič drugače kot drugje, tako da moramo $v$ tem smislu pogledati, kaj je posebnega $\vee$ tej regiji, kar bi določalo primernost ali neprimernost NJM in NWD (in kar zadeva slednje, gre nedvomno za osnovno vprašanje o uporablnosti weberjanizma, starega ali novega, $v$ tej regiji) kot takih oziroma kot rezervoarjev dobrih praks - to pa lahko storimo z analiziranjem izkušenj iz časa pred zlomom. Prav pri vprašanju uporabnosti NJM imamo vrsto držav, ki so nedavno dobile podobne izkušnje in sprejele podobne odločitve, in sicer nove države članice iz Srednje in Vzhodne Evrope - med njimi tudi Slovenija. Če upoštevamo vse razlike in posebnosti, pa tudi težave pri jemanju lekcij, lahko rečemo, da je bila razprava o uporabi NJM v novih državah članicah tako podobna razpravi, ki jo ravno začenja Jugovzhodna Evropa, da je lahko koristna pri ugotavljanju, kaj bi bilo v regiji dobro storiti in čemu bi se bilo dobro izogniti - to pa bi prineslo spoznanja za čas krize in obdobje po njej.

Glavno spoznanje, ki ga nove države članice lahko ponudijo Jugovzhodni Evropi, je nedvomno, naj ne sprejemajo NJM kot paradigme (razen kot posamična orodja NJM). Zdaj namreč vemo, da s „čistkami“ NJM ni mogoče rešiti niti problemov preostanka nekompetentne in nedemokratične birokracije iz prejšnjih časov niti problemov korupcije - preprosto ni 
mogoče, ne glede na to, kako lepo bi to bilo. To pa je nedvomno že lekcija iz časa pred zlomom.

Druga priložnost je koncept NWD, ta pa presega izkušnje novih držav članic, saj $v$ času, ko so se spoprijemale $z$ intenzivno tranzicijo - oziroma zgolj $\vee$ čisto zadnjih letih NWD kot koncept še ni obstajal. Kakor koli že, NWD kot izvedljiva in dobro podprta alternativa, ki človeku omogoča, ne samo da kritizira NJM, temveč da konkretno predstavi povsem razumljiv, sodoben model tega, kako naj bi bila javna uprava videti, je nekaj, kar odgovornim $v$ novih državah članicah ni bilo na voljo. Je posebna ugodnost razmeroma "pozne“ tranzicije, ki jo imajo države Jugovzhodne Evrope in od katere si lahko obetajo precejšnjo korist.

Dobrega življenja $v$ dobri državi Jugovzhodne Evrope (ne glede na zgodovinsko, gospodarsko in kulturno raznolikost regije), ki je konsolidirana in se približuje članstvu $v E U$, usmerjena $v$ mirno in plodno sožitje $v$ globaliziranem, konkurenčnem okolju 21. stoletja po sedanji krizi, si ni mogoče zamisliti brez kakovostne, ustrezne, dobro delujoče javne uprave ter odgovorne, odzivne, kompetentne in zaupanja vredne državne uprave, ki je ključnega pomena tudi za premoščanje še aktualnih vplivov zloma. Zdi se, da je trenutno najboljši model (po katerem bi se lahko zgledovali, ne bi pa ga posnemali) za tak ideal NWD (oziroma nekaj podobnega ali celo presegajočega); zagotovo pa to ni NJM. 